Uludag Univ. J. Fac. Vet. Med.

36 (2017), 1,2: 41-44

\title{
Yerli Irk Bir Kısrakta Vulvar Yassı Hücreli Karsinom Olgusu
}

\author{
Geliş Tarihi:14.03.2017 \\ Düzeltme Tarihi:12.09.2017, Kabul Tarihi:15.12.2017
}

\author{
Kamil SEYREK İNTAŞ ${ }^{1}, \quad$ Volkan İPEK ${ }^{2}, \quad$ E. Sinem ÖZDEMIR SALCI ${ }^{1^{*}}$, \\ Muhittin ZENGIN $^{1}$, Adem DELIGÖNÜL ${ }^{3}$, Gürsel SÖNMEZ ${ }^{2}$
}

\begin{abstract}
Özet: Yerli ırk, 16 yaşlı bir kısrak, genital bölgede sebebi bilinmeyen ve iyileşmeyen yara şikayeti ile kliniğimize getirildi. Kısrağın genel durumu iyiydi ancak genital bölgenin muayenesinde vulvada anüsün alt yarımını kapsayan, fibrotik üremeyle karakterize, yaygın açık bir yara belirlendi. Biyopsi alınarak numuneler patoloji laboratuarına gönderildi. Histopatolojik inceleme sonucu alınan numunelerden yassı hücreli karsinom tanıs1 konuldu. Tedavi için önerilen kemoterapi seçenekleri, kısrağın yaşı ve sağaltımın maliyeti dolayısıyla hasta sahibi tarafından kabul edilmedi. Sunulan bu olgu ile bir kısrakta vulvar yassı hücreli karsinomun klinik ve histopatolojik bulgularının rapor edilmesi ve kliniğimizde çok sık karşılaşılmayan bu neoplazi için olası sağaltım seçeneklerinin tartışılması amaçlanmıştır.
\end{abstract}

Anahtar Kelimeler: Kısrak, vulva, yassı hücreli karsinom.

\section{A Case of Vulvar Squamous Cell Carcinoma in a Native Breed Mare}

\begin{abstract}
A native breed, 16 years old mare was presented to our clinics with the complaint of an idiopathic and non-healing wound on the genital region. General condition of the mare was normal, but an extensive open wound on the vulva, which was extending to ventral part of the anus, characterized by fibrotic proliferation was observed in the examination of the genital region. The biopsy was taken and the samples were sent to pathology laboratory. As a result of histopathological examination, squamous cell carcinoma was diagnosed. The suggested chemotherapy options for treatment were refused by the patient owner because of the age of the horse and the cost of treatment. With this case presentation, reporting of the clinical and histopathological result of vulvar squamous cell carcinoma and possible treatment options for this rare case in a mare was aimed.
\end{abstract}

Key Words: Mare, vulva, squamous cell carcinoma.

\section{Giriş}

Yass1 hücreli karsinom atta ikinci en s1k gözlenen ${ }^{6,9}$, çoğunlukla göz kapağı ve diş genital organlara yerleşen epitelial bir tümördür ${ }^{6}$. Yass1 hücreli karsinom tüm mukokutanöz tümörler arasında \%20 yer kaplamaktadır ve bu tümörlerin dış genital organa yerleşme oranı \%13’tür. Daha çok erkek genital organda gözlenmekte iken, perineal bölgeye yerleşme oranı ise $\% 5{ }^{\prime}$ tir $^{9}$. Metastaz oranı değişkenlik göster- mekle birlikte ${ }^{9}$ çoğunlukla düşüktür, ancak hastalığın ilerleyen evrelerinde lokal ya da regional lenf yumrularına yayılım söz konusudur ${ }^{7}$. Hastalığın ilk evrelerinde nodüler tarzda başlayan lezyonlar ilerleyen evrelerde ülseratif ve nekrotik seyredebilir, tümöral dokunun yüzlek kenarları travmatize olup, firsatçı patojenler ile enfekte olur. Tümoral transformasyon için Equine papillomavirus type 2 (EcPV2) ile enfeksiyonunun gerekli olduğu ancak tek başına yeterli olmadığı bildirilmiştir ${ }^{9}$.

1 Uludağ Üniversitesi, Veteriner Fakültesi, Doğum ve Jinekoloji Anabilim Dalı, 16059, Bursa.

*ssalci@uludag.edu.tr

2 Uludağ Üniversitesi, Veteriner Fakültesi, Patoloji Anabilim Dalı, 16059, Bursa

3 Uludağ Üniversitesi, Tıp Fakültesi, Onkoloji Anabilim Dalı, 16059, Bursa 
Tümörün yerleşimine, büyüklüğüne, yayılımına ve tedavi tutarına göre farklı tedavi seçenekleri bulunmakla birlikte, tedavi seçenekleri arasında cerrahi müdahale, kriyoterapi, hipertermi, radyoterapi, kemoterapi ve fotodinamik terapi yer almaktadır ${ }^{9}$.

Vulvar yassı hücreli karsinom olgusu henüz Türkiye'de rapor edilmemiştir. Sunulan bu olgu ile bir kısrakta karşılaştığımız yassı hücreli karsinomun klinik ve histopatolojik bulgularının rapor edilmesi, ayrıca olası tedavi seçeneklerinin ve tedavi maliyetlerinin tartışılması amaçlanmiştır.

\section{Olgunun Tanımı}

Yerli ırk, 16 yaşlı bir kısrak, atı satın almak isteyen kişi tarafından genital bölgede sebebi bilinmeyen bir yara şikayeti ile Uludağ Üniversitesi Veteriner Fakültesi Doğum ve Jinekoloji Anabilim Dalı Kliniği'ne getirildi. Alınan anamnezde kısrağın genel bir sağlık probleminin olmadığ 1 , ancak vulvasında bir yara bulunduğu, yaranın nasıl şekillendiği konusunda bilgileri olmadığı, bu yaranın tedavi edilip edilemeyeceğinin belirlenmesi amacıyla kliniğe getirildiği bildirildi. Atın sahibine yapılan sorgulamada yaranın en az 6 aydan beri bölgede gözlendiği ve bir türlü iyileşmediği öğrenildi.

\section{Klinik Bulgular}

Kısrağın klinik muayenesinde genel durumunun iyi ve vital parametrelerinin normal olduğu belirlendi. Kısrağın genital bölgesinin muayenesinde vulvada anal sfinkter'in ventral yarımını kapsayan, fibrotik üremeyle karakterize, yaygın, açık, nemli bir yara belirlendi. Muayenede lezyonların vulva ile sinırlı olduğu, vestibulumun vulva sınırı dişında bir yayılma göstermediği belirlendi. Vaginal palpatorik muayenede, servikse kadar olan bölgede herhangi benzer lezyon yoktu ancak perineal bölgede lezyonun vulvadan laterale doğru genişlediği, dorsalde anal sfinkteri de kısmen kapsadığı, çapının yaklaşık 13-15 cm'ye ulaştığı belirlendi (Şekil $1)$.

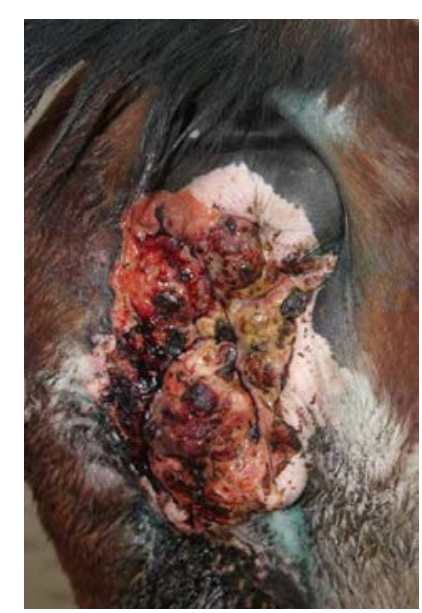

Şekil 1. Klsrakta vulva ve anüsün ventral kismindaki tümöral dokunun görünümü.

Figure 1. Aspect of the tumoral tissue on vulva and ventral part of the anus in a mare.

\section{Histopatolojik Bulgular}

Alınan biyopsi örnekleri Uludağ Üniversitesi Veteriner Fakültesi Patoloji Anabilim Dalı'na gönderildi. Dokular \%10'luk formaldehitte tespit edildi ve rutin takip aşamalarından geçirilerek parafine gömüldü. Bloklar 5 mikron kalınlığında kesilerek hematoksilen-eozin ile boyand 1 ve ş̧1k mikroskobunda incelendi. İncelenen preparatlarda stratum spinozum hücrelerinin dermise doğru üremeler gösterdiği dikkati çekti. Bu hücrelerin eozinofilik sitoplazmalı ve belirgin anizokaryozis sergileyen yuvarlak-oval çekirdeklere sahip olduğu görüldü. Neoplastik hücrelerin bazılarında tek hücre keratinizasyonu ile çok sayıda mitotik figür dikkati çekti (Şekil 2). Belirtilen bulgular 1şığında olguya yassı hücreli karsinom tanısı konuldu.

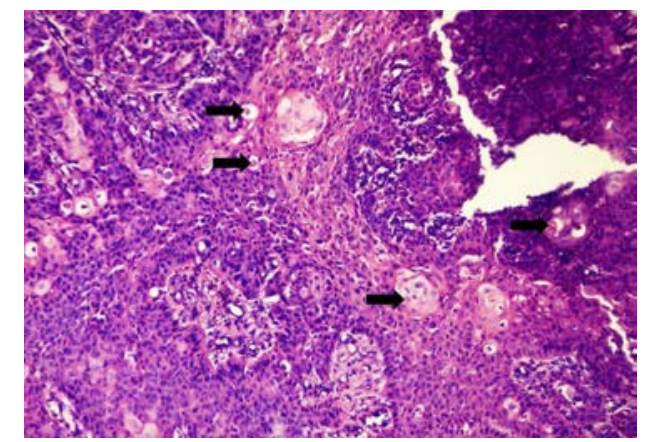

Şekil 2. Solid alanlar şeklinde üremeler gösteren stratum spinozum hücrelerinde gözlenen tek hücre keratinizasyonlarl (oklar), $H \& E, 100 x$.

Figure 2. Individual cell keratinizations (arrows) observing in the stratum spinosum cells proliferating as solid areas, $H \& E$, $100 x$. 


\section{Tedavi Seçenekleri}

Tedavide kombine olarak; platin esaslı antineoplastik cisplatin $4 \mathrm{mg} / \mathrm{m}^{2} / g u ̈ n$, urasil antimetaboliti olarak etki eden pirimidin analoğu bir antineoplastik ajan olan 5-Florasil 250 $\mathrm{mg} / \mathrm{m}^{2} /$ gün 4 günde $1 \mathrm{kez} 4$ hafta boyunca, immunmodülatör etkisinden yararlanmak üzere levamizol 2,5mg/kg dozda haftada $1 \mathrm{kez}, 6 \mathrm{doz}$ olarak ve tümörün hızlı demarkasyonunu sağlamak amaciyla atlarda her bir enjeksiyon için $5 \mathrm{ml}$ 'den fazla kullanılmayan theranekron sc. yolla 10cc olarak 4 gün aralıkla 3 kez tekrarlanarak uygulanması planlanmıştır. Önerilen kemoterapi seçenekleri, kısrağın yașı ve sağaltımin maliyeti dolayısıyla hasta sahibi tarafindan kabul edilmeyerek, eski sahibine iade edileceği bildirildi.

\section{Tartışma}

Yass1 hücreli karsinom tümörleri erken dönemde küçük yüzlek nodüller şeklinde gözlenirken, ilerleyen dönemde epidermal katların hasarı ile ülserasyon alanları ve kötü kokulu nekrozlar gözlenir ${ }^{9}$. Vulva bölgesinde yassı hücreli karsinom gözlenen olgumuzdaki açık, iyileșmeyen yara, tümörün ilerleyen dönemdeki epidermal katların hasarı sonucu ülserasyon ve nekroz alanların görülmesiyle uyumludur.

Tedavi seçenekleri olarak cerrahi yöntemin kemoterapi uygulaması ile kombine olarak uygulandığı 10 yaşlı kısrakta gözlenen vulvar yass1 hücreli karsinom olgusunda, total ekstirpasyon ve peritümoral dokulara ise toplamda $240 \mathrm{mg}$ olarak yaklaşık her 2-3 haftada bir 50 mg cisplatin'in 4 ay süreyle uygulanması önerilerek, tümöral büyümenin kontrol altına alındığg bildirilmiştir ${ }^{5}$. Sunulan kısrak için sedasyon, lokal ve epidural anestezi, cerrahi prosedür ve postoperatif bakıma ilave olarak cisplatin uygulaması toplamda 1140TL mal olacağı hesaplanmıştır. Tedavi operatif ve postoperatif aşamaları içermekte ve ayrıca post operatif komplikasyonlara bağlı sekunder müdahaleleri de gerektirebilmektedir.

İnsanlarda gözlenen vulvar yassı hücreli karsinom olgularında kemo-radyoterapinin etkinliğini radyoterapi ve cisplatin ve 5fluorouracil kombinasyonu uygulamasıyla gösteren çalışmalar mevcuttur ${ }^{2,3}$. Ancak ülkemizde atlar için radyoterapi uygulama olanağı şu anda mevcut değildir.
İnsanlarda servikste gözlenen yassı hücreli karsinom olgularında, cisplatin ve gemcitabine kombinasyonunun etkin bir tedavi olduğu rapor edilmiştir ${ }^{1}$. Bu ilaç kombinasyonunun kısraklarda kullanımına yaptığımız literatür araştımasında rastlanılmamıştır.

Kemoterapi olarak cisplatin, 5Fluorourasil, mitomycin-c, bleomycin kullan1mının detaylarına ilişkin bilgiler bir derlemede aktarılmaktadır ${ }^{9}$. Cisplatin'in tedavi maliyeti $\mathrm{m}^{2}$ ye $20 \mathrm{mg}$ olmak üzere toplamda 5 uygulama için 400 TL'dir. Yine 5-Fluorourasil başlangıç dozu $12 \mathrm{mg} / \mathrm{kg} /$ gün 4 gün süreyle, sonra 6-8-1012. günlerde $6 \mathrm{mg} / \mathrm{kg} /$ gün daha sonra haftada $10-15 \mathrm{mg} / \mathrm{kg} /$ gün 4 hafta süreyle uygulanmas1 önerilmiștir. Olgumuzda bu ilaç kullanılarak sarf edilecek maaliyet 500TL olarak hesaplanmıştır. Mitomycin-c haftada bir kez 3 hafta boyunca $20 \mathrm{mg}$ total doz olarak uygulanması öngörülmektedir. Olgumuzda uygulama olarak düșünüldügünde bu ilacın her dozu için fiyat $128 \mathrm{TL}$ yani toplam tedavi maliyeti uygulama sayıs1 itibariyle yaklaşık 360 TL civarında belirlenmiştir. Bleocin S bir haftada $3 \mathrm{kez}$ 80mg dozdan totalde $300 \mathrm{mg}$ doza kadar uygulamas1 yapılabilir. Yine bu ilaç için toplam masraf yaklaşık 800 TL'yi bulmaktadır.

Kısrak yassı hücreli karsinom olgusunda denenen intratümöral cisplatin uygulamasının pratik ve efektif bir tedavi olduğu bildirilmiş, intratümöral $0,97 \mathrm{mg} / \mathrm{cm}^{3}$ dozda 2 hafta arayla 4 uygulamanın etkili olduğu görülmüştür ${ }^{10}$. Bu uygulamanın tedavi masrafi da $50 \mathrm{TL}$ civarında olmaktadır.

28 yaşlı bir başka kısrakta vulva dudaklarını, perineum ve anüsü kapsayan rektal fistül ile komplike bir olguda end-on kolostomi tedavi seçeneği olarak denenmiş, ayrıca bir kemoterapi uygulanmadığ 1 olguda, kısrağın genel durumu 14 ay sabit tutulduktan sonra tekrar eden letarji, iştahsızlık ve zayıflama sonucu ötenazi edildiği bildirilmiştir ${ }^{11}$.

25 yaşlı bir kısrakta gelişen papilloma virusu ile enfekte vulvar yassı hücreli karsinom olgusu rapor edilmiştir. Rapor edilen olguda tedavi olarak tümoral dokunun lazer ile eksizyonu ve vulvar doku çevresine 5-Fluorourasil enjeksiyonu uygulanmış, tedavi lezyonların nüksü gerçekleşmeyene kadar devam etmiştir ${ }^{8}$.

Karşılaştığımız olguda platin esaslı antineoplastik Cisplatin $4 \mathrm{mg} / \mathrm{m}^{2} /$ gün, urasil antimetaboliti olarak etki eden pirimidin analoğu bir antineoplastik ajan olan 5-Fluorourasil 250 $\mathrm{mg} / \mathrm{m}^{2} /$ gün her 96 saatte bir 4 hafta uygulamas1- 
n1 ve immunmodülatör etkisinden yararlanmak üzere Levamizol 2,5mg/kg dozda haftada $1 \mathrm{kez}$ ve 6 dozda ve tümörün hızlı demarkasyonunu sağlamak amaciyla atlarda her bir enjeksiyon lokalizasyonu için 5ml'den fazlası kullanılmayan Theranekron subkutan yolla 10cc olarak 4 gün aralıklarla $3 \mathrm{kez}$ tekrarlanarak uygulanması planlanmıştır. Toplam tedavi maliyeti ise sonunda 705 TL olarak hesaplanmıştır ${ }^{2,4}$.

Sonuç olarak, farklı cerrahi ve kemoterapi yöntemleri veya bunların kombinasyonları kullanılarak atlarda yassı hücreli karsinomun \% 60-90 oranında başarı ile tedavisi yapılabilmekte, ancak 14-21 ay süreler sonunda yeni tümör gelişimleriyle karşılaş1labilmektedir. Tedavi maliyetleri $10-15 \mathrm{~cm}$ çaplı yassı hücreli karsinom için 50-1140 TL arasında değişmektedir. $\mathrm{Bu}$ şartlarda yassı hücreli karsinom tedavisinde farklı tedavi seçenekleri bulunmaktadır, fakat saha şartlarında hastanın yaşı ve tedavi masrafları tedavinin tercih edilip edilmemesi bakımından belirleyici etkenlerdir.

\section{Kaynaklar}

1. Brewer, C.A., Blessing, J.A., Nagourney, R.A., McMeekin, D.S., Lele, S., Zweizig, S.L. 2006. Cisplatin plus gemcitabine in previously treated squamous cell carcinoma of the cervix: A phase II study of the Gynecologic Oncology Group. Gynecol. Oncol., 100, 385-388.

2. Cunningham, M.J., Goyer, R.P., Gibbons, S.K., Kredentser, D.C., Malfetano, J.H., Keys, H. 1997. Primary radiation, cisplatin, and 5fluorouracil for advanced squamous carcinoma of the vulva. Gynecol. Oncol., 66, 258-261.
3. Eifel, P.J., Morris, M., Burke, T.W., Levenback, C., Gershenson, D.M. 1995. Prolonged continuous infusion cisplatin and 5-fluorouracil with radiation for locally advanced carcinoma of the vulva. Gynecol. Oncol., 59, 51-56.

4. Fortier, L.A., Mac Harg, M.A. 1994. Topical use of 5-fluorouracil for treatment of squamous cell carcinoma of the external genitalia of horses: 11 cases. J. Am. Vet. Med. Assoc, 205 (8), 1183-5

5. Joyce, J.B. 2013. Treatment of a large vulvar squamous cell carcinoma by radical excision and injectable cisplation. Erişim: http://www.itarget.com.br/newclients/abraveq201 2/down/2012/weva/124.pdf

6. Perrier, M., Schwarz, T., Gonzalez, O., Brounts, S. 2010. Squamous cell carcinoma invading the right temporomandibular joint in a Belgian mare. Can. Vet. J., 51, 885-887.

7. Scheck, J.L. 2005. Treatment of an ocular squamous cell carcinoma in a stallion with atrial fibrillation. Can. Vet. J., 46, 922-924.

8. Smith, M.A., Levine, D.G., Getman, L.M., Parente, E.J., Engiles, J.B. 2009. Vulvar squamous cell carcinoma in situ within viral papillomas in an aged Quarter Horse mare. Equine Vet. Educ., 21(1), 11-16.

9. Taylor, S., Haldorson, G. 2013. A review of equine mucocutaneous squamous cell carcinoma. Equine Vet. Educ., 25 (7), 374-378.

10. Theon, A.P., Pascae, J.R., Carlson, G.P., Krag, D.N. 1993. Intratumoral chemotherapy with cisplatin in oily emulsion in horses. J. Am. Vet. Med. Assoc., 202(2), 261-7.

11. Wilson, D.A. 1994. Management of perianal squamous cell carcinoma with permanent colostomy in a mare. J. Am. Vet Med. Assoc., 205(10), 1430-1. 